2018-03

\title{
Understanding the Role of Local Food in Sustaining Chinese Destinations
}

Chen, Q

http://hdl.handle.net/10026.1/11096

10.1080/13683500.2018.1444020

Current Issues in Tourism

Taylor \& Francis (Routledge)

All content in PEARL is protected by copyright law. Author manuscripts are made available in accordance with publisher policies. Please cite only the published version using the details provided on the item record or document. In the absence of an open licence (e.g. Creative Commons), permissions for further reuse of content should be sought from the publisher or author. 


\section{Understanding the Role of Local Food in Sustaining Chinese Destinations}

\section{Author Details:}

1.Dr. Qian Chen* Yangzhou University, China (Corresponding author*)

School of Tourism and Culinary Science (Food Science \& Engineering), Yangzhou University, Yangzhou, China

Address: 196 Huayang West Avenue, Yangzhou, China

Tel.: +8615856669933

Email address: qianchen0303@outlook.com

2. Dr. Rong Huang Plymouth University, UK

School of Tourism and Hospitality, Plymouth University, Plymouth, UK, PL4 8AA Tel.: +4401752232836

Email: rong.huang@plymouth.ac.uk

\section{Author Bio}

Dr. Qian Chen (qianchen0303@outlook.com) is a Lecturer from Yangzhou University (China). She holds a $\mathrm{PhD}$ from University of Plymouth (UK). Her research interests include special interest tourism, tourism marketing, and tourist behaviour.

Dr. Rong Huang is an Associate Professor from University of Plymouth (UK). Her research interests focus on aspects of the tourism phenomenon and published articles in relation to international student travel, employability, food tourism and intermediation. 


\title{
Understanding the Role of Local Food in Sustaining Chinese Destinations
}

\begin{abstract}
Food is a sustainable part of destination tourism. However, few studies attempt to separate and examine the role played by local foods within tourists' overall experience when claiming the benefits that local foods can bring to a destination. Using Mainland China as the case in point, this study aims to evaluate the potential for destinations to use local food as a sustainable marketing tool. This is achieved through examining how local food, as part of the tourist experience, can contribute to tourists' destination loyalty. This study proposes a structural model addressing the potential relationships between tourist food-related behaviours (tourists' food-related motivation, information search, food involvement, and food satisfaction) and destination loyalty among domestic tourists in China. Useable data was collected from 1353 respondents at eight destinations in China, this was screened and analysed with SPSS 21 and partial least squares-structural equation modelling (PLS-SEM). The results reveal the positive correlation between tourists' food satisfaction and destination loyalty, confirming the value of local food in China as a sustainable marketing tool. However, the paper highlights that tourists' food-related motivation, information search, and involvement are not in direct correlation to their destination loyalty. Possible implications for destination marketers and researchers are provided.
\end{abstract}


Keywords: local food, sustainable tourism, tourist behaviour, destination loyalty

\section{Introduction}

Tourism is a holistic experience, in which food nourishes both the body and the soul of tourists (Hjalager \& Johansen, 2013). Specifically, food is a necessity, not only satisfying the physical needs of tourists, but also assisting in the enhancement of tourists' social relationships, excitement, and learning. With food being an inextricable part of the touristic experience, it is widely acknowledged by researchers (Everett \& Aitchison, 2008; Horng \& Tsai, 2012) that numerous aspects of food add great value to destinations, including economy, culture, destination identity, and local sustainability. Against a background of wide appeals for sustainability within the development of the tourism industry, growing attention has been noted into the role of food as a sustainable resource (Everett \& Aitchison, 2008; Everett \& Slocum, 2013; Sims, 2009).

However, an analysis of academic literature indicates that the research into the role of food in destination sustainable development has yet to be fully explored. Very few studies manage to provide empirical data from the demand side, which could indicate how food can be utilised by destinations to contribute to the development of sustainable tourism. Moreover the Western world is the main focus of current literature in food and sustainable tourism (Everett \& Aitchison, 2008; Hjalager \& Johansen, 2013; Sims, 2009) with a deficiency of literature focusing on countries 
such as China, Japan, Korea, Singapore, Thailand, and India.

This paper therefore focuses on Mainland China, an area with a diversity of food resources and a profound food culture ( $\mathrm{Du}, 2012)$. An increasing number of environmental problems are associated with the development of the Chinese tourism industry, so the need to develop sustainable tourism is well noted (Zhang, Ji, \& Zhu, 2013). Previous studies (Xu \& Fox, 2014; Wan \& Li, 2011) have contributed to the research of Chinese sustainable tourism, however, a review of both English and Chinese literature reveals that few studies have managed to offer insights into how to utilise food as a sustainable tourism resources and thus contribute to the sustainable development of the tourism industry.

Against the above background, this study aims to evaluate the role of food as a sustainable marketing tool in Chinese destinations. This study constructs a systematic model addressing whether, and how, food as part of tourist experience can influence tourist behaviours and contribute to their loyalty intentions to destinations. Although China-focused, the findings and the theoretical model constructed in this study will not only shed light on the marketing strategies for destination marketers in China, but also benefit other regions that would like to utilise food as a sustainable marketing tool for contributing to a destination's development. 


\section{Literature Review}

\section{Food \& Sustainable Tourism}

As one of the essential elements, researchers (Boyne, Williams, \& Hall, 2003; Lin, Pearson, \& Cai, 2011) notice that many tourist destinations increasingly use food as a popular initiative within the development of local tourism. There are a myriad of benefits associated with local foods in a destination (Handszuh, 2000). In particular, local food holds a lot of potential for contributing to the development of local sustainable tourism (Berno, Kline \& Wolf, 2014; He, 2006; Sims, 2009). As can be seen below, a volume of research and information shows that the significance of food to sustainable tourism can be understood from different aspects (Mgonja, Backman, Backman, Moore and Hallo, 2016; Sims, 2009).

Firstly, local foods contribute to the economic sustainability of destinations (Sims, 2009). Food is a sustainable way to increase tourist spending and extend the tourist season (Everett \& Aitchison, 2008). Tourist consumption of local foods will support the local economy through promoting local food production, generating revenues, and potentially retaining tourism earnings in the region (Mgnoja et al., 2016). Secondly, local foods assist in the development of the environmental sustainability of a destination. Tourists who consume local foods can generate market opportunities and support diversification of local agriculture. It can create benefits by conserving traditional farming landscapes, addressing environmental preservation, and encouraging sustainable development of agriculture (Everett \& 
Aitchison, 2008; Sims, 2009). Lastly, local foods assist in improving the social and cultural sustainability of destinations. According to Sims (2009), local foods are defined as authentic products representing the place and culture of a destination. In this way the tourists' consumption of local foods can enhance a destination's identity within the tourist experience, improve the involvement of the local community and contribute to the social and cultural development of local sustainable tourism (Mgonja et al., 2016; Quan \& Wang, 2004).

The use of local food can contribute, both directly and indirectly, to various elements of sustainability in a specific area (du Rand \& Health, 2006; Everett \& Slocum, 2013; Sims, 2009). Gössling and Hall (2013) highlight that the production and consumption of food are significant aspects in the development of sustainable tourism. Local food and drink products can improve the economic, environmental, social and cultural sustainability of both tourism, and the rural host community, through generating revenues, supporting local businesses, encouraging sustainable agricultural practices, and meeting the needs of tourists for local experience and a sense of place (Berno et al., 2014; Sims, 2009).

However, although several studies (Everett \& Aitchison, 2008; Paratt, 2013; Sims, 2009) claim the role of food as an important vehicle for delivering sustainable tourism to destinations, very few studies manage to provide empirical data from the demand side evaluating the role that local food plays in tourists' experience. 
Moreover, many researchers (e.g. Lee, Packer, \& Scott, 2015; McKercher \& Chan, 2005; Smith, Pitts, \& Litvin, 2012) express their concerns that the significance of food as a motivation for travel has been exaggerated and that many studies have assumed food-related activities are a valid proxy for travel motives. Therefore, it is important to understand the true value of food within the overall travel decisions of tourists and their consumer behaviours and how local food can be utilised by destinations to contribute to the development of sustainable tourism needs further investigation.

\section{Food-related Behaviour \& Tourist Destination Loyalty}

Consumer behaviour is a constant decision-making process (Gilbert, 1991). According to Engel, Kollat and Blackwell (1968), the grand model of consumer behaviour consists of five main phases, which include problem/need recognition, information search, and evaluation of alternatives, purchase, and post-purchase behaviour. To understand tourists' food-related behaviours, the grand model of consumer behaviour is adapted in the current research, with suitable factors identified throughout distinct phases.

Recognition of consumers' needs is the first step for marketers (Engel et al., 1968). To understand why customers do what they do is to basically understand their motivations (Solomon, Bamossy, Askegaard, \& Hogg, 2013). According to Boyne et al. (2003), the importance of food in tourists' motivation varies among people 
and is likely to influence tourists' attitudes and behaviours. Therefore, tourists' food-related motivations assist in recognising the needs of the tourist market, and in predicting tourists' food-related behaviours at destinations. Tourist food-related motivation is thus identified as the first factor in evaluating the role of food in influencing tourists' motivation.

Once need has been recognised, potential tourists start searching for adequate information and solutions to meet that need (Fodness \& Murray, 1997). Faced with large amounts of information, Ab Karim and Chi (2010) propose that the travellers responded to information based on the type and credibility of information sources. Therefore, it is vital for destination marketers to understand how tourists acquire knowledge and find out what, to them, is a perceived credible source of information (Ab Karim \& Chi, 2010). Searching for information refers to travellers using different types of information sources to facilitate trip planning; and is thus identified as the second factor that might affect their travel behaviours and decision making (Gursoy \& Chen, 2000). When searching for relevant information, tourists might evaluate alternative options before making their final choice. However, as this phase is the direct result of the information search, and a difficulty exists in identifying a suitable factor to evaluate this phase, no separate factor has been noted.

To accord with the stage of 'purchase' in the consumer behaviour model, tourist 
food involvement is claimed as the equivalent factor examining tourists' on-site food-related behaviours and activities. According to Havitz and Dimanche (1999:123), the concept of involvement refers to an "unobservable state of motivation, arousal, or interest toward a recreational activity or product" and has been widely employed to understand tourist attitudes and behaviours. In addition, Bell and Marshall (2003) highlight that a tourist's level of involvement with food is likely to vary across people. Therefore, tourist food involvement is significant in revealing tourist behaviours toward food (Kim, Suh \& Eves, 2010).

When the 'purchase' is finished, the next stage is about tourists' post-purchase behaviours, this is when tourists will form their evaluation of their on-site experience. According to Rust and Oliver (1994), the level of satisfaction is the outcome generated from a comparison between performance and expectations. Due to a positive correlation with the quality of experience, satisfaction is an important indicator of tourist experience in that it creates positive feelings (Lee \& Chang, 2012). Therefore, tourist food satisfaction is identified as the most suitable factor for this stage.

Based on the above discussion, the four factors of 'food-related motivation', 'information search', 'food involvement', and 'food satisfaction' have been identified as underlying tourist food-related behaviour. However, for the purpose of understanding the importance of a tourist's food experience during their entire 
destination experience, and to predict future travel demand in relation to food, an evaluative factor needs to be identified. Based on a comprehensive review of relevant research (Kim \& Brown, 2012; Lee, Huang \& Yeh, 2010; Yoon \& Uysal, 2005), tourist destination loyalty is noted as the evaluative factor for assessing tourist food experience. Yoon and Uysal (2005) mention that tourists' positive experience of the service, products and other resources provided at tourism destinations can result in loyalty behaviours such as repeat visits and positive recommendations. Consequently, destination loyalty is identified as the assessment factor of tourists' food experience.

Following the identification of the above factors, it is important to examine potential relationships between the factors; about how tourist behaviours across various stages integrate and influence tourist destination loyalty. This is achieved in the following four ways:

Firstly, according to existing studies, there is a lack of research investigating the specific relationships between tourist food-related motivations and the tourists' food-related attitudes and behaviours. However, a few studies, in more general contexts, have presented causal relationships between motivation and different indicators including information search (Moorthy, Ratchford, \& Talukdar, 1997), involvement (Kim, 2008; Kim, Woo \& Uysal, 2015; Prebensen, Woo, Chen, \& Uysal, 2013), satisfaction (Lee \& Beeler, 2009), and destination loyalty (Kim, 2008; 
Yoon \& Uysal, 2005). Consequently, the following hypotheses are proposed:

H1: Food-related motivation has a positive influence on information search.

H2: Food-related motivation has a positive influence on food involvement.

H3: Food-related motivation has a positive influence on food satisfaction.

H4: Food-related motivation has a positive influence on destination loyalty.

Secondly, according to Fodness and Murray (1998) and Gursoy and Chen (2000), the information acquired and used by potential customers might affect their decision-making processes and travel behaviours. Previous studies have revealed the significance of tourist information search behaviour on tourist level of involvement (Xiang \& Law, 2013), level of overall satisfaction (Gursoy \& McCleary, 2004), and further behaviour intentions (Correia \& Pimpão, 2008). Therefore, it is postulated:

H5: Information search has a positive influence on food involvement.

H6: Information search has a positive influence on food satisfaction.

H7: Information search has a positive influence on destination loyalty.

Thirdly, involvement is thus highlighted of significance in predicting and interpreting tourist experience (Havitz \& Dimanche, 1999). Previous studies have noted the impacts of tourists' level of involvement on tourists' satisfaction (Chiu et al., 2014; Lee \& Beeler, 2009; Kim, 2008; Kim et al., 2015), and tourists' loyalty (Iwasaki \& 
Havitz, 2004; Kyle et al., 2004; Lee \& Chang, 2012). Therefore, the following hypotheses are drawn:

H8: Food involvement has a positive influence on food satisfaction.

H9: Food involvement has a positive influence on destination loyalty.

Lastly, Baker and Crompton (2000) mention that measuring tourist' satisfaction offers predictions on tourists' future behavioural intentions. Researchers (Chen \& Tsai 2007; Kim, 2008) have shown their support through revealing a significant association between tourists' level of satisfaction and loyalty intentions. Consequently, it is predicted:

H10: Food satisfaction has a positive influence on destination loyalty.

To summarize, this study investigates the underlying dimensions of food-related behaviour and examines the impact of food-related behaviour on tourist destination loyalty. Based on the grand model of consumer behaviour, as well as the relationships shown among the constructs from previous research, specific hypotheses on the potential relationships among the constructs have all been identified. The proposed theoretical model is shown as Figure 1.

Please Insert Figure 1 


\section{Methodology}

\section{Questionnaire Design and Measurement of Construct}

This study adopted the quantitative survey approach using a structured questionnaire to test the hypothesized theoretical model. The questionnaire was firstly designed in English and then translated into Chinese using a back-translation approach to ensure consistency (Birslin, 1976). The questionnaire contained six parts; measuring tourist food-related motivation, information search, food involvement, food satisfaction, destination loyalty and demographic information. The demographic profiles of respondents were examined in terms of gender, age, and educational level. As for the constructs of the theoretical model, each construct was designed with a multi-item measurement scale because the single-item scale might fail to capture all the attributes of the construct (Churchill, 1979). Respondents were asked to rate each item using a 7-point Likert scale, with 1 being "strongly disagree" and 7 being "strongly agree".

In terms of measuring tourist food-related motivation, a six-item scale approach was developed from studies by Beer, Ottenbacher, and Harrington (2012), McKercher et al. (2008), and Kim, Suh, and Eves (2010). The construct of information search was optimally operationalised as the use of information sources suggested by Fodness and Murray (1997). A multi-attribute approach was developed in this study to measure tourists' ratings of the importance of various information sources (Ab Karim \& Chi, 2010; Kotler \& Armstrong, 2010). To 
measure tourist food involvement, an eight-item uni-dimensional scale was adapted from the study by Sparks (2007), which was originally modified from Zaichkowsky’s (1985) Personal Involvement Inventory (PII) scale. As for the construct of food satisfaction, five items were derived from the previous studies (Bosque \& Martín, 2008, Mason \& Paggiaro, 2012; Žabkar, Brenčič, \& Dmitrovi, 2010), and for the construct of destination loyalty, a three-item scale was adapted from previous research (Žabkar et al., 2010).

To ensure the face validity of the questionnaire design, the questionnaire was subject to the expert reviews both academically and practically, in both Chinese and English contexts. Specifically, the questionnaire was sent to local tour operators in China, Chinese destination marketers, and both English and Chinese academics and professionals. Based on the evaluation of the questionnaire and comments made by the experts, a few changes were made to improve the questionnaire and thus form the second draft. Then, a pilot study was conducted in Yangzhou, Jiangsu Province in China on $30^{\text {th }}$ March, $5^{\text {th }}$ April, and $6^{\text {th }}$ April 2014. A total of 109 usable responses were collected, and the collected data was analysed through SPSS version 21 to determine whether the measurement scales of the constructs were valid and reliable. Due to the analysis results of the constructs all being above the suggested statistical threshold (Hair, Hult, Ringle, \& Sarstedt 2014), the constructs were confirmed to be of satisfactory reliability and validity, and the questionnaire was finalised for the main survey. 


\section{Data Collection}

The main survey was conducted at eight chosen destinations (Changsha, Chengdu, Guangzhou, Nanjing, Hangzhou, Hefei, Qingdao, and Xiamen) in China in May and June 2014. The eight destinations were selected as they represent the 'Eight Major Schools of Cuisine' in China (Lu, Chuan, Yue, Min, Su, Zhe, Xiang, and Hui) based upon geographical regions that divide Chinese cuisine into eight main categories each with their own traditions and characteristics (Du \& Li, 2010; Jiang, 2013). For example, 'Chuan' is characterised by spicy and pungent flavours, 'Su' is renowned for light and sweet tastes, while ' $\mathrm{Lu}$ ' frequently uses shallots and garlic as seasonings (Jiang, 2013). The eight cuisines together show the characteristics of Chinese culinary culture.

At each survey destination, the questionnaire was conducted using an interviewer-completed approach by a few research assistants at the departure lounges of coach stations, train stations, and airports. Research assistants were instructed to approach respondents using the next-to-pass non-probability sampling technique (Tourism and Recreation Research Unit, 1983). If the approached person showed willingness to continue the questionnaire interview, screening questions were applied by the interviewers to confirm the appropriateness of each respondent. Firstly, respondents were asked whether or not they were domestic tourists in China; secondly, respondents were provided with the definition of local food, and asked whether they had a local food experience during their travels. In total 1427 
questionnaires were collected of which 1353 questionnaires were useable.

\section{Data Analysis}

To test the presented hypotheses in the study, Structural Equation Modelling (SEM) with a Partial Least Squares (PLS) approach was applied to test the theoretical model using the software application of SmartPLS 2.0 software (Ringle, Wende, \& Will 2005). PLS-SEM was used over other methods for two reasons.

First, PLS estimates "all path coefficients and multiple individual item loadings simultaneously, and consequently enables researchers to avoid biased and inconsistent parameter estimates" (Loureiro and González, 2008, p.125). PLS-SEM does not require a high level of normal data distribution, while being able to handle different sample sizes, and dealing with both reflective and formative constructs (Hair, Ringle, \& Sarstedt, 2011). Given that the dataset in this study is fairly large, with 1,353 valid observations and the proposed model consists of both reflective and formative constructs, then PLS-SEM is preferred.

Second, PLS-SEM is a prediction oriented modelling technique (Henseler, Ringle, \& Sinkovics, 2009). As one of the first attempts from a process perspective assessing how tourist food experience influences tourist destination loyalty, the current research focuses on predicting the value of food within the tourist experience and the marketing of a destination. Therefore, considering that the 
phenomenon and measurement models are relatively new, and the aim is for theory development and prediction, then PLS was viewed as the most appropriate approach.

Before applying the PLS-SEM approach to test the model, it is suggested that the data was screened using version SPSS version 21.0 to ensure its quality. The results showed that neither a non-response bias nor missing values and outliers were detected. Thus, the data was appropriate for further analysis using PLS-SEM.

\section{Results}

\section{Profile of the respondents}

There was a slight higher distribution of females among respondents in terms of gender: $52.9 \%$ were female, and $47.1 \%$ male; this may be explained by the fact that females are more likely to respond to food-related surveys (Robinson \& Getz, 2014). The two dominant age groups were those aged between 18 and 26 years old (30.7\%) and 26 to 35 years old (37.5\%). Around $86.7 \%$ of the respondents had at least a college degree, which may be a result of the recent expansion of higher education in China (Wang \& Liu, 2011). The sample is characterised as being well educated. In addition, through analysis, the profile of the respondents also has certain influences on the food-related behaviours of tourists, details see Chen and Huang (2018). 


\section{Evaluation of Measurement Model}

The theoretical model presented in this study was analysed through a two-step approach (i.e. measurement model and structural model). The measurement model is evaluated to verify both the reflective and formative constructs. Table 1 below presents the reliability and validity of constructs with reflective measurement model specifications.

\section{Please Insert Table 1}

The assessment of reflective construct reliability and validity was based on internal consistency reliability, indicator reliability, convergent validity, and discriminant validity. Firstly, according to Table 1, Cronbach's alpha and composite reliability values of the constructs all exceeded 0.80 , which were above the minimal acceptable threshold of 0.70 (Nunnally, 1978), showing high internal consistency reliability of the constructs. Secondly, the item loadings of all the indicators were above the 0.70 thresholds, which supported the indicator reliability. Thirdly, the reflective measures have satisfactory convergent validity because the average variance extracted (AVE) values of the constructs were all above the threshold of 0.50 (Henseler et al., 2009). Lastly, based on Fornell and Lacker's (1981) criterion, the square root of AVE of each reflective construct was above the inter-construct correlations (as shown in Table 2). Therefore, the reflective constructs of the model have satisfactory discriminant validity. 
Please Insert Table 2

Concerning the formative construct (i.e information search), content validity was initially examined at both indicator and construct levels. At the indicator level, the assessment is suggested as being based upon examining an item's weight and the loading, and using the bootstrapping procedure to test their significance (Hair et al., 2011). The conduct of a bootstrapping procedure (Table 3) revealed that all loadings for the 'Information Search' items were significant at a significance level of $1 \%$, however, the significance of some indicators' weights were not significant. Nevertheless, those indicators were still recommended to be retained in the model as Hair et al. (2011) argued that only when both the outer weight and outer loading are non-significant should the formative indicator be considered for removal.

Please Insert Table 3

Unlike reflective indicators, high levels of collinearity between formative indicators need to be avoided due to their impact on the estimation of weights and statistical significance (Diamantopoulos \& Winklhofer, 2001). The VIF values of the formative indictors shown in Table 3 ranged from 1.794 to 2.705 , lower than the threshold 5, therefore no potential collinearity problems exist in the formative construct in the study. Consequently, with the assessments of both the reflective and formative measurement model being satisfactory, the evaluation can proceed to the 
structural model.

\section{Evaluation of Structural Model}

The structural model was assessed to test the hypothesized relationships among the constructs. Specifically, the quality of the structural model in PLS was evaluated in terms of the model's explanatory power and predictable capabilities using non-parametrical tests (Götz, Liehr-Gobbers, \& Krafft, 2010). The potential issues of multi-collinearity among the latent variables were checked. The results confirmed that no collinearity problem exists as the values of variance inflation factor (VIF) are much lower than the threshold of 5 (Chin, 1998). The coefficient of determination $\left(\mathrm{R}^{2}\right)$ as an essential assessment criterion was applied and $\mathrm{R}^{2}$ values of $0.19,0.33$, and 0.67 are described as weak, moderate, and substantial respectively for endogenous latent variables (Chin, 1998). The percentages of explained variance $\left(\mathrm{R}^{2}\right.$ values) (Table 4$)$ for the variables of information search, food involvement, food satisfaction, and destination loyalty are 10.3\%, 39.5\%, $25.0 \%$, and $41.7 \%$, respectively. Although the $\mathrm{R}^{2}$ value of the construct information search is not very high, it is still above the minimum limit of 0.10 according to the guidelines. The model was also evaluated through the Stone-Geisser's $\mathrm{Q}^{2}$ test, which was developed to observe the predictive relevance of the constructs (Geisser, 1974). To obtain the $\mathrm{Q}^{2}$ values, the blindfolding procedures were conducted. As shown in Table 4, all $\mathrm{Q}^{2}$ values are significantly above the threshold of zero (Henseler et al., 2009), implying sufficient predictive relevance of the exogenous 
constructs. Therefore, the structural model has satisfactory predictive validity.

Please Insert Table 4

Finally, a bootstrapping procedure was performed with 5000 iterations of re-sampling to obtain the path coefficients and t-statistics of the hypothesized relationships (Chin, 1998). Based on the path coefficients and the associated significance, the testing results of the hypotheses were shown in Table 5.

Please Insert Table 5

Food-related motivation influences information search at $\beta=0.316, p<0.01$ and food involvement at $\beta=0.568, \mathrm{p}<0.01$; while food-related motivation does not directly influence food satisfaction, and destination loyalty. Tourist information search was in positive correlation to food involvement at $\beta=0.628, \mathrm{p}<0.01$, however, its direct relationship with food satisfaction and destination loyalty, respectively was not supported. Food involvement was found to positively influence food satisfaction ( $\beta=$ $0.429, \mathrm{p}<0.01)$, whereas the direct effect on destination loyalty $(\beta=0.057, \mathrm{p}>0.1)$ was not significant. Finally, the direct relationship between food satisfaction and destination loyalty was proved significantly positive at $\beta=0.603, p<0.01$. Figure 2 below shows the analytic results of the structural model. 


\section{Mediation Analysis}

For the purpose of obtaining a more thorough understanding of how, why, or when insignificant relationships occurred (Nunkoo, Ramkissoon, \& Gursoy, 2013), in addition to the above evaluation, conducting an analysis of potential mediation among constructs was suggested. Based on the analysis procedures noted by Hair et al. (2014), Table 6 (below) shows the results of the potential mediation effects analysis in the current study.

Please Insert Table 6

The results confirmed the partial mediating role of food involvement on the relationship between food-related motivation and food satisfaction (VAF=50.3\%), as well as the relationship between information search and food satisfaction (VAF $=71.3 \%$ ). In addition, the partial mediating effects of food satisfaction on the relationship between information search and destination loyalty (VAF=51.9\%), and the relationship between food involvement and destination loyalty were verified $(\mathrm{VAF}=55.2 \%)$

\section{Discussions}

This study integrated key variables of tourist food-related behaviour and destination loyalty into a research model focused on domestic tourists in China. The model evaluated whether and how food, as part of tourist experience, contributes to their 
loyalty intentions towards destinations in China.

The positive correlation between tourist food satisfaction and destination loyalty acknowledged the value of developing food as a marketing tool in China. Many studies (Chen \& Tsai 2007; Kim, 2008) acknowledged the positive relationship between tourists' overall satisfaction and their loyalty intentions. According to Weiermair and Fuchs (1999), the overall satisfaction that tourists have towards a destination is positively linked with each dimension of that destination. It is thus understandable that tourists' food satisfaction, as one dimension of their overall satisfaction, has an influence on their loyalty intentions towards the destination. In addition, Kivela and Crotts (2006) noticed that the positive beliefs that tourists have toward their local cuisine experience could prompt them to visit the destination and experience the cuisine again (Kivela \& Crotts, 2006). Therefore, the value of developing food as a marketing tool was supported.

However, according to the results, no positive direct relationship was shown between destination loyalty with tourist food-related motivation, information search, and food involvement, respectively. The results implied that tourists who have higher motivation in food, higher engagement with information search, and higher involvement with food would not necessarily have higher loyalty intentions towards a particular destination (Zhang, 2012). Nevertheless, these results seems to disagree with a previous study by Kim, Suh and Eves (2010), which showed that tourists who 
perceive higher importance of food in their travel motivation are more likely to be satisfied with their food festival experience, and more likely to return to the food festival. In addition, Kim, Suh and Eves (2010) noted a significant positive relationship between tourist food involvement and tourist loyalty and thus it contrasted with the results of this study. It is suggested that the contrast might be explained by the different settings of the two studies with their study set in the context of a food festival in South Korea, while this study is set at a destination level in China. Therefore, our results indicated that destinations in China that would like to use food as a marketing tool should pay equal attention to individuals with both low and high levels of food-related motivation, information search, and food involvement, as every domestic tourist could be a loyal and repeat visitor to that destination.

Because tourist destination loyalty was only in direct correlation to tourist food satisfaction, the focus for destination marketers should be to maximise the tourists' satisfaction level with their food experience (Wan \& Chan, 2013; Zhang, 2012). According to the results, tourist food satisfaction was directly influenced by tourist food involvement, which was positively related to tourist food-related motivation and information search. In addition to the direct impacts, the mediation analysis above also highlighted the mediating role of food involvement, and food satisfaction, respectively, in the model. Specifically, the mediating role of food involvement further enhanced the importance of food involvement in monitoring the satisfaction level of tourist with their food experience regardless of their food-related motivation 
and information search behaviours. It was explained that involvement is a precondition to some types of behavioural consequences and satisfaction (Lee \& Beeler, 2009; Prebensen et al., 2013). The level of involvement affects the level of participation, which positively influences the creation of experience satisfaction (Kim, 2008; Prebensen et al., 2013). Therefore, in line with the study by Kim (2008) that identified the mediating role of involvement between motivation and satisfaction to predict the travel demand within the university student market, tourist food involvement might be useful in predicting tourists' travel demand within the food tourism market.

Moreover, the study also highlighted the mediating effects of food satisfaction. Although the mediating role of satisfaction has not been well addressed in the food tourism context; in the similar context of wine tourism, Lee and Chang (2012) highlighted the role of satisfaction in mediating the relationship between activity involvement and wine tourists' loyalty intentions. In addition, the result of the study was in line with several studies (Castro et al., 2007; Lee, 2009) that have acknowledged the mediating role of satisfaction in the tourist behavioural model. Consequently, maximising tourists' satisfaction level with their local food experience is of foremost significance if that destination wishes to retain the loyalty intentions of those tourists. 


\section{Conclusions and Implications}

This study is of an exploratory nature to understand how, from a tourist behaviour perspective, a destination could utilise food for marketing purposes. The results confirmed the value of local food to a destination, and supported the development of local food as a marketing tool for a destination. With a thorough investigation from the perspective of tourist experience, the specific relationships are supposed to provide suggestions to destination marketers about how to utilise effectively local food to retain and attract tourists. A range of practical implications is listed below:

Firstly, destinations should create positive, unique images of destination food through effective positioning and differentiation to attract tourists' attention (Chen \& Huang, 2016; Lin, Pearson, \& Cai, 2011; Okumus, Okumus, \& McKercher, 2007). Based on the positive relationship shown between tourist food-related motivation and information search, tourists who perceive higher importance of food in their travel motivation tend to do more information search on food prior to travel. Therefore destinations that are already promoting themselves to the public using sophisticated materials (e.g good images and relevant information) related to local foods are likely to attract this potential group of tourists (Okumus et al., 2007). Thus it is suggested that destinations should appreciate their local food resources and pay detailed attention to how those resources are presented and promoted to the public.

Secondly, based on the positive relationship shown between information search and 
tourist food involvement, destinations should utilise a range of different channels of information sources to distribute the information (Ab Karim \& Chi, 2010). Destination marketers should aim to create positive 'word of mouth' publicity of that destination's food so as to increase people's willingness to visit destinations for food purposes, and also actively seek regular feedback from tourists who had recently visited that destinations in order to monitor, or possibly avert, any negative 'word-of-mouth' publicity of the food at that destination (Cheng, Lam, \& Hsu, 2006). Furthermore, destinations should use a multi-channel approach towards the distribution of their information; for example publishing brochures, magazines and booklets on local food culture and restaurants, presenting destination food-related documentaries or TV shows, sharing information on websites and social media, and developing good relationship with travel agencies (Ab Karim \& Chi, 2010; Chen \& Huang, 2016).

Thirdly, the significance of food involvement has been highlighted in the model on influencing tourists' food satisfaction. Consequently, destination marketers should develop different types of food-related activities to attract and encourage tourists to get involved with destination food, such as identifying distinctive or traditional food products, holding food shows or food festivals, providing cooking demonstrations or cookery classes, and organising distinctive food-themed tours (Huang 2009; Chen \& Huang, 2016). In addition to the development of different food-related activities, destination marketers should pay attention to ensuring and improving the performance 
and quality of the food-related activities offered by the destination (Croce \& Perri, 2010). Having tourists' expectations of the destination food involvement met and further exceeded will contribute to tourists' satisfaction with their food experience, and lead to strengthening their loyalty intentions.

This study is one of the first attempts to construct a structural model examining the interrelationships between tourist food-related behaviours and their destination loyalty. Through the employment of a new generation of SEM (PLS-SEM), it offers insights to destination marketers on how to effectively assess the value of local food to the destination marketing. Additionally, as an aspect of cultural tourism, this study might also benefit similar research areas such as wine tourism, and other forms of cultural tourism. Specifically, the model might be tested and applied in different contexts of cultural tourism revealing how to achieve successful destination marketing through understanding tourist experience (Charters and Ali-Knight, 2002; Horng \& Tsai, 2012).

This study examined tourists' food-related behaviours across different stages, and provided insights for destination marketers to delve deeper into the food-related behaviours of tourists prior to conducting food-related marketing activities. Kim, Eves, and Scarles (2013) argued that research into tourists' local food consumption and food experience is still in its infancy. Compared to the existing dominating research perspective from the supply side in the field, this study contributed to the 
body of existing research on tourists' food experience, and provided empirical evidence on the food experience of Chinese tourists when they travelled in China.

\section{Limitations and Future Research}

Despite the research contributions, several limitations of this study need to be considered to provide direction for future research. Firstly, in terms of the proposed theoretical model, due to the exploratory nature, the current model was limited in the number of variables used. Additional factors such as food-related personal traits, previous experience, perceived value/quality might also have impacts on tourists' food experience and possibly influence tourists' destination loyalty. Future research should focus on testing the theoretical model with the inclusion of additional factors and proposing a more comprehensive model.

Secondly, limitation was noted on the selection of data collection locations. Concerns might be raised that the destinations with rich food resources and specialities might have impacts on the role of food influencing tourists' experience and loyalty. Respondents might be argued to be more likely to have a higher rating of the importance of food at those destinations. However, in the special context of China, due to every destination possessing its own food resources, speciality dish and variations of Chinese cuisine, the limitations are inevitable.

Thirdly, this study was conducted at eight different destinations at a city level in 
China and there are concerns on the generalisation of the results to represent the whole of China. Future study could be replicated in a destination of a smaller size in China. Additionally, the sample used in the study was limited to Chinese domestic tourists. It may be of concern that the sample could fail to verify the wider generalizability of the results. The theoretical model in the study could be tested with different samples from different destinations or regions in the future.

\section{References}

Ab Karim, S. \& Chi, C.G.Q. (2010). Culinary tourism as a destination attraction: an empirical examination of destinations' food image. Journal of Hospitality Marketing \& Management, 19(6), 531-555. DOI: 10.1080/19368623.2010.493064

Baker, D.A. \& Crompton, J.L. (2000). Quality, satisfaction and behavioural intentions. Annals of Tourism Research, 27(3), 785-804.

Beer, C. L., Ottenbacher, M.C., \& Harrington, R. J. (2012). Food tourism implementation in the Black Forest destination. Journal of Culinary Science \& Technology, 10(2), 106-128. DOI: 10.1080/15428052.2012.677601

Bell, R. \& Marshall, D. W. (2003). The construct of food involvement in behavioral research: Scale development and validation. Appetite, 40(3), 235-244. DOI: 10.1016/S0195-6663(03)00009-6

Berno, T., Kline, C. \& Wolf, E. (2014) Food tourism in academia. In Wolf, E., Bussell, J., Campbell, C., Lange-Faria, W. \& McAree, K. (Eds). Have Fork Will Travel: A Practical Handbook for Food and Drink Tourism Professionals. Portland: World Food Travel Association, 309-321.

Boniface, P. (2003). Tasting tourism: traveling for food and drink. Burlington: Ashgate Publishing.

Bosque, I.R.D., \& Martin, H.S. (2008). Tourism satisfaction: A cognitive-affective model. Annals of Tourism Research, 35, 551-573. DOI: 10.1016/j.annals.2008.02.006

Boyne, S., Hall, D. \& Williams, F. (2003). Policy, support and promotion for food-related tourism initiatives: a marketing approach to regional development. In 
Hall, C. M. (ed). Wine, Food and Tourism Marketing, Birmingham: The Harworth Press, 131-153.

Brislin, R.W. (1976). Comparative research methodology: cross-cultural studies. International Journal of Psychology, 11 (3), 215-229. DOI: $10.1080 / 0020759760824735$

Castro, C. B., Armario, M. E. \& Ruiz, D. M. (2007). The influence of market heterogeneity on the relationship between a destination's image and tourists' future behaviour. Tourism Management, 28(1), 175-187. DOI: 10.1016/j.tourman.2005.11.013

Charters, S. \& Ali-Knight, J (2002). Who is the wine tourist? Tourism Management 23(3), 311-319.

Chen, Q., \& Huang, R. (2016). Understanding the importance of food tourism to Chongqing, China. Journal of Vacation Marketing, 22(1), 42-54. DOI: $10.1177 / 1356766715589427$

Chen, C.F. \& Tsai, D. (2007). How destination image and evaluative factors affect behavioural intentions? Tourism Management, 28(4), 1115-1122.

Cheng, S., Lam T. \& Hsu, C. H. C. (2006). Negative world-of-mouth communication intention: An application of the theory of planned behaviour. Journal of Hospitality and Tourism Research, 30(1), 95-116. DOI: 10.1177/1096348005284269

Chin, W.W. (1998). The partial least squares approach for structural equation modelling. In Marcoulides, G.A. (Ed.), Modern Methods for Business Research. Mahwah, NJ: Lawrence Erlbaum Associates, 295-336.

Chi, C. G.Q. \& Qu, H. (2008). Examining the structural relationships of destination image, tourist satisfaction and destination loyalty: an integrated approach. Tourism Management, 29(4), 624-636. DOI: 10.2307/3150876

Churchill, G. A. (1979). A paradigm for developing better measures of marketing constructs. Journal of Marketing Research, 16(1), 64-73. DOI: 10.2307/3150876

Cohen, S.A., Prayag, G. \& Moital, M. (2014). Consumer behaviour in tourism: Concepts, influences and opportunities. Current Issues in Tourism. 17, 872-909. DOI: $10.1080 / 13683500.2013 .850064$

Correia, A. \& Pimpão, A. (2008). Decision-making processes of Portuguese tourist travelling to South America and Africa. International Journal of Culture, Tourism and Hospitality Research, 2(4), 330-373.

Croce, E., \& Perri, G. (2010). Food and wine tourism: Integrating food, travel and territory. CABI. 
Diamantopoulos, A. \& Winklhofer, H.M. (2001). Index construction with formative indicators: an alternative to scale development. Journal of Marketing Research. 38(2), 269-77. Retrieved from: http://www.jstor.org/stable/1558630

Du Rand, G. E., \& Heath, E. (2006). Towards a framework for food tourism as element of destination marketing. Current Issues in Tourism, 9(3), 206-234. DOI: 10.1300/J073v14n03_06

Du,Y. (2012). 'A bite of China' brings along the heat of food tourism. Hangzhou Daily. [Online]. Retrieved October 3, 2015, from: http://fashion.ifeng.com/travel/roll/detail_2012_06/08/15152455_0.shtml.

Engel, J. F., Kollat, D. J. \& Blackwell, R. D. (1968). Consumer behaviour. New York: Holt, Rinehart, and Winston.

Everett, S. \& Aitchison, C. (2008). The role of food tourism in sustaining regional identity: a case study of Cornwall, South West England. Journal of Sustainable Tourism, 16(2), 150-167. DOI: 10.2167/jost696.0

Everett, S. \& Slocum, S.L. (2013). Food and tourism: an effective partnership? A UK-based review, Journal of Sustainable Tourism, 21(6), 789-809, DOI:10.1080/09669582.2012.741601

Fodness, D. \& Murray, B. (1997). Tourist information search. Annals of Tourism Research, 24 (3), 503-23. DOI: 10.1016/S0160-7383(97)00009-1

Fornell, C. \& Larcker, D.F. (1981). Evaluating structural equation models with unobservable and measurement error. Journal of Marketing Research, 34(2), 161-188. DOI: $10.2307 / 3151312$

Götz, O., Liehr-Gobbers, K. \& Krafft, M. (2010). Evaluation of structural equation models using the partial least squares (PLS) approach. In Vinzi, V.E. Chin, W.W and Gössling,S. \& Hall, M (2013). Sustainable Culinary Systems: An introduction. In M,Hall \& S.Gössling (Eds.), Sustainable Culinary Systems: Local Foods, Innovation, Tourism and Hospitality (pp.3-44). Routledge: Abingdon.

Gilbert, D. C. (1991). Consumer behaviour in tourism. In Cooper, C. P. (Ed.). Progress in tourism, recreation and hospitality management. Lymington, Hants, UK: Belhaven Press, 78-105

Gursoy, D. \& Chen, J.S. (2000). Competitive analysis of cross-cultural information search behavior. Tourism Management, 21 (6), 583-590. DOI: 10.1016/S0261-5177(00)00005-4 
Gursoy, D. \& McCleary, K.W (2004). An integrative model of tourists' information search behavior. Annals of Tourism Research, 31(2), 353-373.

Handszuh, H. (2000). Local food in tourism policies. Paper presented at the International Conference on Local Food and Tourism, Larnaka, Cyprus

Hair, J.F., Ringle, C.M. \& Sarstedt, M. (2011). PLS-SEM: Indeed a silver bullet. Journal of Marketing Theory and Practice, 19(2), 139-151. DOI: 10.2753/MTP1069-6679190202

Hair, J. F., Hult, G. T., Ringle, C. M., \& Sarstedt, M. (2014). A Primer on Partial Least Squares Structural Equation Modelling (PLS-SEM).Thousand Oaks, CA: Sage.

Havitz, M. \& Dimanche, F. (1999), Leisure involvement revisited: drive properties and paradoxes. Journal of Leisure Research, 31(2), 122-149.

Henseler, J., Ringle, C.M., \& Sinkovics, R.R. (2009). The use of partial least squares path modelling in international marketing. Advances in International Marketing. 20 (1), 277-320. DOI: 10.1108/S1474-7979

He, L.P. (2006). Discussing the Food Tourism Resources in Changsha. Journal of Changsha University, 20 (3), 10-12.

Henderson, J. C. (2009). Food tourism reviewed. British Food Journal. 111(4), 317-332. DOI: /10.1108/00070700910951470

Horng, J.S. \& Tsai,C.Y. (2012). Constructing indicators of culinary tourism strategy: an application of resource-based theory, Journal of Travel \& Tourism Marketing, 29(8), 796-816. DOI: 10.1080/10548408.2012.730945

Hjalager, A.M. \& Johansen, P.H. (2013). Food tourism in protected areas sustainability for producers, the environment and tourism? Journal of Sustainable Tourism, 21(3), 417-433. DOI: 10.1080/09669582.2012.708041

Huang, R. (2009). The role of food in promoting Chinese regions on the web. Int. J. Tourism Policy, 2 (4), 289-305. DOI: 10.1504/IJTP.2009.028715

Jin, B. H. (1999). Chinese culinary culture development and characteristics. Heilongjiang National Series, 3(58), 87-93. DOI:

Kim, Y. G., Suh, B. W. \& Eves, A. (2010). The relationships between food-related personality traits, satisfaction, and loyalty among visitors attending food events and festivals. International Journal of Hospitality Management, 22(2), 216-226. DOI: 10.1016/j.ijhm.2009.10.015 
Kim, A. K. \& Brown, G. (2012). Understanding the relationships between perceived travel experiences, overall satisfaction, and destination loyalty, Anatolia: An International. Journal of Tourism and Hospitality Research, 23(3), 328-347. DOI: $10.1080 / 13032917.2012 .696272$

Kim, K. (2008). Analysis of structural equation model for the student pleasure travel market: Motivation, involvement, satisfaction, and destination loyalty. Journal of Travel \& Tourism Marketing, 24(4), 297-313. DOI: $10.1080 / 10548400802156802$

Kim, Y.G., Eves, A. \& Scarles, C. (2013). Empirical verification of a conceptual model of local food consumption at a tourist destination. International Journal of Hospitality Management, 33(1), 484-489. DOI: 10.1016/j.ijhm.2012.06.005

Kim, H.L., Woo, E.J. \& Uysal, M. (2015). Tourism experience and quality of life among elderly tourists. Tourism management, 46, 465-476.

Kivela, J. \& Crotts, J. C. (2006). Tourism and gastronomy: Gastronomy's influence on how tourists experience a destination. Journal of Hospitality \& Tourism Research, 30(3), 354-377. DOI: 10.1177/1096348006286797

Lee, J. \& Beeler, C. (2009). An investigation of predictors of satisfaction and future intention: links to motivation, involvement, and service quality in a local festival. Event Management, 13(1), 17-29. DOI: 10.3727/152599509789130584

Lee, T. H. \& Chang, Y. S. (2012). The influence of experiential marketing and activity involvement on the loyalty intentions of wine tourists in Taiwan. Leisure Studies, 31(1), 103-121

Lee, C.F., Huang, H.I. \& Yeh, H.R. (2010). Developing an evaluation model for destination attractiveness: sustainable forest recreation tourism in Taiwan. Journal of Sustainable Tourism, 18(6), 811. DOI: 10.1080/09669581003690478

Lee, K.H., Packer, J., \& Scott, N. (2015). Travel lifestyle preferences and destination activity choices of Slow Food members and non-members. Tourism Management, 46(0), 1-10.

Loureiro, S.M.C., Sardinha, I.M.D. \& Reijnders, L. (2012). The effect of corporate social responsibility on consumer satisfaction and perceived value: The case of the automobile industry sector in Portugal. Journal of Cleaner Production, 1-7.DOI: 10.1016/j.jclepro.2012.07.003

Lo, A., Cheung, C. \& Law, R. (2002). Information search behaviour of Hong Kong's inbound tourists-A comparison of business and leisure tourists. Journal of Travel \& Tourism Marketing, 13(3), 61-80 
Lin, Y., Pearson, T. \& Cai, L. (2011). Food as form of destination identity: A tourism destination brand perspective. Tourism and Hospitality Research, 11, 30-48. DOI: doi.org/10.1057/thr.2010.22

Mason, M.C., \& Paggiaro, A. (2012). Investigating the role of festivalscape in culinary tourism: The case of food and wine events. Tourism Management, 33(6), 1329-1336. DOI:: 10.1016/j.tourman.2011.12.016

McKercher, B.F.,Okumus, F., \& Okumus, B. (2008). Food tourism as a viable market segment: It's all how you cook the numbers! Journal of Travel \&Tourism Marketing, 25(2), 137-148. DOI: 10.1080/10548400802402404

McKercher, B., \& Chan, A. (2005). How special is special interest tourism? Journal of Travel Research, 44(1), 21-31.

Meler, M. \& Cerovic, Z. (2003). Food marketing in the function of tourist product development. British Food Journal, 105 (3), 175-192. DOI:

Mgonja, J.T., Backman,K.F., Backman,S.J., Moore, D.D., \& Hallo, J.C. (2016). A structural model to assess international visitors' perceptions about local foods in Tanzania. Journal of Sustainable Tourism.1-21.[Published Online. DOI: 10.1080/09669582.2016.1250768

Moorthy, S., Ratchford, B. R. \& Talukdar, D.(1997). Consumer information search revisited: Theory and empirical analysis. Journal of Consumer Research, 23(4), 263-277.

Nunnally, J.C. (1978). Psychometric Theory. $2^{\text {nd }}$ edition. New York: McGraw-Hill.

Nunkoo, R., Ramkissoon, H. \& Gursoy, D. (2013). Use of structural equation modelling in tourism research: past, present and future. Journal of Travel Research, 52 (6), 759-71. DOI: 10.1177/0047287513478503

Okumus,B.,Okumus,F. \& McKercher, B.F.(2007). Incorporating local and internationalcuisines in the marketing of tourism destinations: The cases of Hong Kong and Turkey. Tourism Management, 28(1), 253-261. DOI: 10.1016/j.tourman.2005.12.020

Prebensen, N., Woo, E., Chen, J. \& Uysal, M. (2013). Motivation and involvement as antecedents of the perceived value of the destination experience. Journal of Travel Research, 52(2), 253-264. DOI: 10.1177/0047287512461181

Quan, S., \& Wang, N. (2004). Towards a structural model of the tourist experience: An illustration from food experiences in tourism. Tourism Management, 25(3), 297-305. DOI: 10.1016/S0261-5177(03)00130-4

Sims, R. (2009). Food, place and authenticity: local food and the sustainable tourism 
Experience. Journal of Sustainable Tourism, 17(3), 321-336. DOI: 10.1080/09669580802359293

Smith, W. W., Pitts, R. E., \& Litvin, S. W. (2012). Travel and leisure activity participation. Annals of Tourism Research, 39(4), 2207-2210.

Wan, Y.K., \& Li, X.P. (2011). Sustainability of Tourism Development in Macao, China. International Journal of Tourism Research, 15(1), 52-65. DOI: $10.1002 /$ jtr.873

Wan, Y.K. \& Chan, S.H. (2013). Factors that Affect the Levels of Tourists' Satisfaction and Loyalty towards Food Festivals: a Case Study of Macau. International Journal of Tourism Research. 15(3), 226-240

Weiermair, K.\& Fuchs, M. (1999) Measuring Tourist Judgments on Service Quality. Annals of Tourism Research, 26,1004-1021. DOI: 10.1016/S0160-7383(99)00037-7

Xiang, Z. \& Law, R. (2013). Online competitive information space for hotels: an information search perspective. Journal of Hospitality Marketing \& Management, 22(5), 530-546.

Xu, F.F., \& Fox, D. (2014). Modelling attitudes to nature, tourism and sustainable development in national parks: A survey of visitors in China and the UK. Tourism Management. 45, 142-158. DOI: 10.1016/j.tourman.2014.03.005

Yoon, Y. \& Uysal, M. (2005). An examination of the effects of motivation and satisfaction on destination loyalty: A structural model. Tourism Management, 26(1), 45-56. DOI: 10.1016/j.tourman.2003.08.016

Žabkar, V., Brenčič, M.M. \& Dmitrović, T. (2010). Modelling perceived quality, visitor satisfaction and behavioural intentions at the destination level. Tourism Management, 31(4), 537-546. DOI: 10.1016/j.tourman.2009.06.005

Zhang,J.K., Ji, M. \& Zhu, P.X. (2013). Research on Chinese Sustainable Tourism in the $21^{\text {st }}$ Century. Economic Management Journal, 1, 121-129. Retrieved from: http://kreader.cnki.net/Kreader/CatalogViewPage.aspx?dbCode $=C J F Q \&$ filename $=J J G U 201301015 \&$ tablename $=$ CJFDLAST2015\& compose $=\&$ first $=1 \&$ uid $=$

Zhang, T. (2012). A study on the effect of food tourism motivation on tourist satisfaction and behaviour intention. Tourism Tribune, 27(10), 78-84 
Table 1. Assessment of the reflective measurement model

\begin{tabular}{|c|c|c|c|c|}
\hline Constructs and Items & Loading & $\begin{array}{l}\text { Cranach's } \\
\text { Alpha }\end{array}$ & $\begin{array}{l}\text { Composite } \\
\text { reliability }\end{array}$ & AVE \\
\hline \multicolumn{5}{|l|}{ Food-related Motivation } \\
\hline $\begin{array}{l}\text { Food plays an important role in my } \\
\text { destination choice. }\end{array}$ & 0.797 & 0.879 & 0.909 & 0.625 \\
\hline $\begin{array}{l}\text { Prior to my trip, I planned food choices to } \\
\text { experience local culture. }\end{array}$ & 0.822 & & & \\
\hline $\begin{array}{l}\text { I decided on destinations to visit only based } \\
\text { on the foods I wanted to experience. }\end{array}$ & 0.735 & & & \\
\hline $\begin{array}{l}\text { I usually do some research about the local } \\
\text { food or restaurants prior to my trip. }\end{array}$ & 0.784 & & & \\
\hline $\begin{array}{l}\text { Prior to my trip, one thing I anticipate is } \\
\text { eating the food there. }\end{array}$ & 0.846 & & & \\
\hline $\begin{array}{l}\text { I like trying different styles or types of food } \\
\text { during travel. }\end{array}$ & 0.753 & & & \\
\hline \multicolumn{5}{|l|}{ Food Involvement } \\
\hline Interesting & 0.786 & 0.925 & 0.939 & 0.656 \\
\hline Appealing & 0.821 & & & \\
\hline Valuable & 0.793 & & & \\
\hline Exciting & 0.847 & & & \\
\hline Stimulating & 0.790 & & & \\
\hline Desirable & 0.821 & & & \\
\hline Wanted & 0.823 & & & \\
\hline Mean a lot & 0.798 & & & \\
\hline \multicolumn{5}{|l|}{ Food Satisfaction } \\
\hline $\begin{array}{l}\text { The food experience gave me high } \\
\text { satisfaction. }\end{array}$ & 0.856 & 0.910 & 0.933 & 0.736 \\
\hline $\begin{array}{l}\text { My choice to taste the local cuisine was a } \\
\text { wise one. }\end{array}$ & 0.866 & & & \\
\hline $\begin{array}{l}\text { The food experience gave me a sense of } \\
\text { joy. }\end{array}$ & 0.887 & & & \\
\hline The food experienced met my expectations. & 0.877 & & & \\
\hline $\begin{array}{l}\text { The food experienced exceeded my } \\
\text { expectation. } \\
\text { Destination Loyalty }\end{array}$ & 0.800 & & & \\
\hline $\begin{array}{l}\text { I would like to recommend the destination } \\
\text { to others. }\end{array}$ & 0.889 & 0.834 & 0.909 & 0.751 \\
\hline $\begin{array}{l}\text { I will spread positive word of mouth about } \\
\text { the destination. }\end{array}$ & 0.885 & & & \\
\hline I will visit the destination again. & 0.824 & & & \\
\hline
\end{tabular}

Table 2. Inter-construct correlations and the square root of AVE 


\begin{tabular}{lllll}
\hline & $\begin{array}{l}\text { Food-related } \\
\text { motivation }\end{array}$ & $\begin{array}{l}\text { Food } \\
\text { involvement }\end{array}$ & $\begin{array}{l}\text { Food } \\
\text { satisfaction }\end{array}$ & $\begin{array}{l}\text { Destination } \\
\text { loyalty }\end{array}$ \\
\hline $\begin{array}{l}\text { Food-related } \\
\text { motivation }\end{array}$ & $\mathbf{0 . 7 9 1}$ & & & \\
Food involvement & 0.614 & $\mathbf{0 . 8 1 0}$ & & \\
Food satisfaction & 0.344 & 0.490 & $\mathbf{0 . 8 5 8}$ & \\
Destination Loyalty & 0.248 & 0.363 & 0.641 & $\mathbf{0 . 8 6 7}$ \\
\hline
\end{tabular}

Note: Square root of average variance extracted (AVE) is shown on the diagonal of the matrix in boldface. 
Table 3. Assessment of the formative measurement model

\begin{tabular}{|l|l|l|l|}
\hline Construct and Items & $\begin{array}{l}\text { Item } \\
\text { weight }\end{array}$ & $\begin{array}{l}\text { Item } \\
\text { loading }\end{array}$ & $\begin{array}{l}\text { Variance } \\
\text { inflation } \\
\text { factor }\end{array}$ \\
\hline Information Search & & & \\
\hline Newspaper/magazines ads & $0.184^{*}$ & $0.646^{* * *}$ & 1.963 \\
\hline Brochures & 0.100 & $0.635^{* * *}$ & 2.174 \\
\hline Television, Radio commercials & 0.046 & $0.608^{* * *}$ & 2.365 \\
\hline Internet advertising & 0.024 & $0.549^{* * *}$ & 2.032 \\
\hline Travel agency ads & $0.185^{* *}$ & $0.564^{* * *}$ & 1.959 \\
\hline Outdoor media ads & 0.074 & $0.508^{* * *}$ & 1.973 \\
\hline Print media columns/travel news & 0.005 & $0.639^{* * *}$ & 2.075 \\
\hline Television, Radio programs/travel news & $0.181^{*}$ & $0.694^{* * *}$ & 2.093 \\
\hline Websites information/travel news & $0.303^{* * *}$ & $0.767 * * *$ & 1.971 \\
\hline Social media (forums, blogs, twitter & 0.115 & $0.666^{* * *}$ & 1.794 \\
\hline Friends/families recommendation & 0.058 & $0.568^{* * *}$ & 2.266 \\
\hline Word of mouth from other tourists & $0.245^{* *}$ & $0.699^{* * *}$ & 2.211 \\
\hline Past experience or general knowledge & $0.204^{*}$ & $0.650^{* * * *}$ & 2.705 \\
\hline
\end{tabular}

Note: ${ }^{*} \mathrm{p}<0.10 ; \quad * * \mathrm{p}<0.05 ; \quad * * * \mathrm{p}<0.01$ (t-value) 
Table 4 Explained variance $\left(R^{2}\right)$ and the prediction relevance $\left(Q^{2}\right)$ of the constructs

\begin{tabular}{|l|l|l|}
\hline $\begin{array}{l}\text { Endogenous } \\
\text { constructs }\end{array}$ & $\begin{array}{l}\text { Coefficients of } \\
\text { determination }\left(\mathrm{R}^{2}\right)\end{array}$ & $\begin{array}{l}\text { Prediction } \\
\text { Variance }\left(\mathrm{Q}^{2}\right)\end{array}$ \\
\hline Information search & 0.103 & 0.035 \\
\hline Food involvement & 0.395 & 0.242 \\
\hline Food satisfaction & 0.250 & 0.172 \\
\hline Destination loyalty & 0.417 & 0.295 \\
\hline
\end{tabular}

Table 5. Results of Hypotheses Testing

\begin{tabular}{|l|l|l|l|}
\hline Hypotheses & $\begin{array}{l}\text { Path } \\
\text { coefficient }\end{array}$ & t-values & Result \\
\hline H1:Food-related motivation $\rightarrow$ Information search & $0.316^{* * *}$ & 10.593 & Supported \\
\hline H2:Food-related motivation $\rightarrow$ Food involvement & $0.568^{* * *}$ & 25.155 & Supported \\
\hline H3:Food-related motivation $\rightarrow$ Food Satisfaction & 0.052 & 1.417 & Rejected \\
\hline H4:Food-related motivation $\rightarrow$ Destination loyalty & -0.012 & 0.398 & Rejected \\
\hline H5:Information search $\rightarrow$ Food involvement & $0.145^{* * *}$ & 5.833 & Supported \\
\hline H6: Information search $\rightarrow$ Food satisfaction & 0.090 & 3.239 & Rejected \\
\hline
\end{tabular}




\begin{tabular}{|l|l|l|l|}
\hline H7: Information search $\rightarrow$ Destination loyalty & 0.056 & 2.328 & Rejected \\
\hline H8: Food involvement $\rightarrow$ Food satisfaction & $0.429 * * *$ & 12.807 & Supported \\
\hline H9: Food involvement $\rightarrow$ Destination loyalty & 0.057 & 1.799 & Rejected \\
\hline H10: Food satisfaction $\rightarrow$ Destination loyalty & $0.603 * * *$ & 22.144 & Supported \\
\hline
\end{tabular}

Note: ${ }^{*} \mathrm{p}<0.10 ; \quad{ }^{* *} \mathrm{p}<0.05 ; \quad * * * \mathrm{p}<0.01$ (t-value)

Table 6. Test of mediation through Bootstrapping

\begin{tabular}{|c|c|c|c|c|c|c|c|}
\hline & \multirow{2}{*}{$\begin{array}{l}\text { Mediator } \\
\text { variable }\end{array}$} & \multicolumn{2}{|c|}{ First Criteria } & \multicolumn{2}{|c|}{ Second Criteria } & \multirow{2}{*}{$\begin{array}{l}\text { Third } \\
\text { Criteria } \\
(\mathrm{VAF} \%)\end{array}$} & \multirow[t]{2}{*}{ Mediation } \\
\hline & & $\begin{array}{l}\text { Direct } \\
\text { effect } \\
\text { (t value) }\end{array}$ & $\begin{array}{l}\text { Sig. } \\
\text { (p value) }\end{array}$ & $\begin{array}{l}\text { Indirect } \\
\text { effect } \\
\text { (t value) }\end{array}$ & $\begin{array}{l}\text { Sig. } \\
\text { (p value) }\end{array}$ & & \\
\hline $\begin{array}{l}\text { MOT -> } \\
\text { SAT }\end{array}$ & INVO & $\begin{array}{l}0.295 \\
(9.221)\end{array}$ & $\begin{array}{l}* * * \\
(0.000)\end{array}$ & 0.292 & $\begin{array}{l}* * * \\
(0.000)\end{array}$ & $50.3 \%$ & $\begin{array}{l}\text { Partial } \\
\text { mediation }\end{array}$ \\
\hline
\end{tabular}




\begin{tabular}{|l|l|l|l|l|l|l|l|}
\hline $\begin{array}{l}\text { MOT -> } \\
\text { SAT }\end{array}$ & IS & $\begin{array}{l}0.069 \\
(1.886)\end{array}$ & NS & \multicolumn{3}{|l|}{} & $\begin{array}{l}\text { No } \\
\text { mediation }\end{array}$ \\
\hline IS->SAT & INVO & $\begin{array}{l}0.154 \\
(5.190)\end{array}$ & $\begin{array}{l}* * * \\
(0.000)\end{array}$ & 0.062 & $\begin{array}{l}* * * \\
(0.000)\end{array}$ & $71.3 \%$ & $\begin{array}{l}\text { Partial } \\
\text { mediation }\end{array}$ \\
\hline $\begin{array}{l}\text { IS->LO } \\
\text { YA }\end{array}$ & SAT & $\begin{array}{l}0.108 \\
(3.476)\end{array}$ & $\begin{array}{l}* * * \\
(0.001)\end{array}$ & 0.100 & $\begin{array}{l}* * * \\
(0.000)\end{array}$ & $51.9 \%$ & $\begin{array}{l}\text { Partial } \\
\text { mediation }\end{array}$ \\
\hline $\begin{array}{l}\text { INVO-> } \\
\text { LOYA }\end{array}$ & SAT & $\begin{array}{l}0.319 \\
(8.900)\end{array}$ & $\begin{array}{l}* * * \\
(0.000)\end{array}$ & 0.259 & $\begin{array}{l}* * * \\
(0.000)\end{array}$ & $55.2 \%$ & $\begin{array}{l}\text { Partial } \\
\text { mediation }\end{array}$ \\
\hline $\begin{array}{l}\text { MOT-> } \\
\text { LOYA }\end{array}$ & INVO & $\begin{array}{l}0.015 \\
(0.576)\end{array}$ & NS & \multicolumn{5}{|}{} & & $\begin{array}{l}\text { No } \\
\text { mediation }\end{array}$ \\
\hline $\begin{array}{l}\text { MOT-> } \\
\text { LOYA }\end{array}$ & SAT & $\begin{array}{l}0.019 \\
(0.539)\end{array}$ & NS & & & & $\begin{array}{l}\text { No } \\
\text { mediation }\end{array}$ \\
\hline
\end{tabular}

Note: NS - Non-significant

$*$ Significant at $\mathrm{p}<0.10 . \quad * *$ Significant at $\mathrm{p}<0.05 . * * *$ Significant at $\mathrm{p}<0.01$ 
Figure 1. Theoretical Model

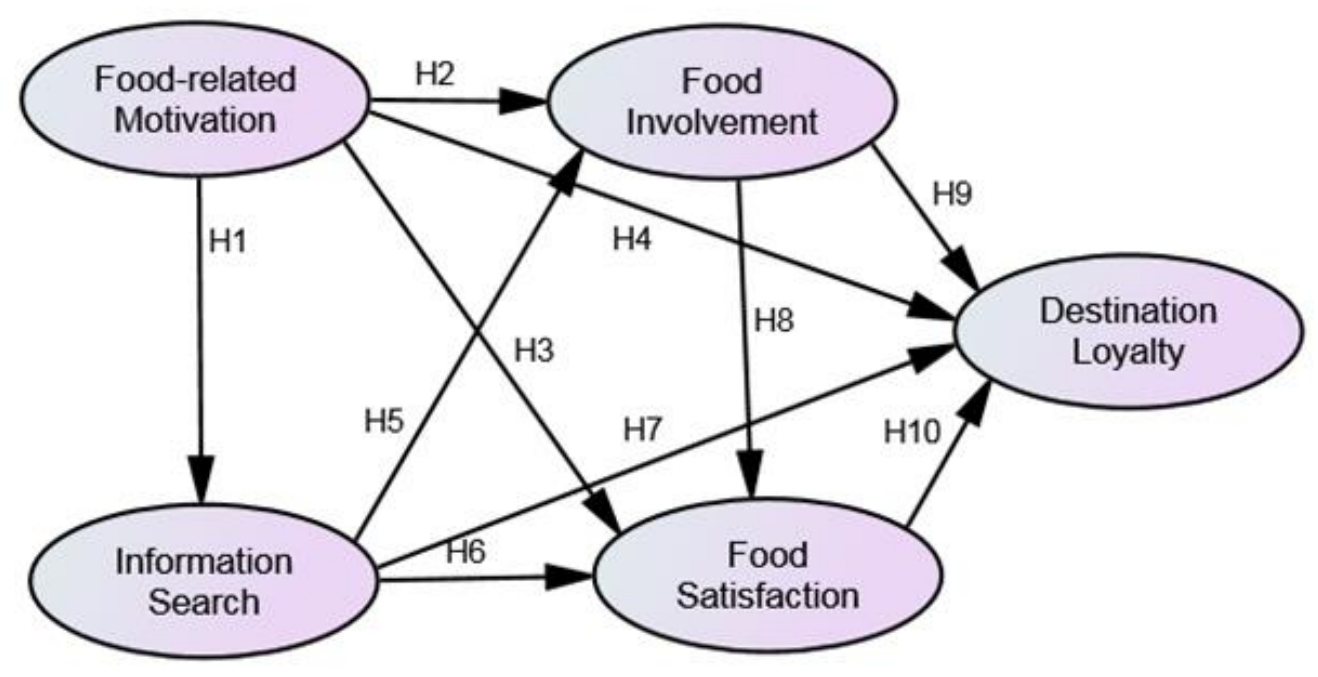


Figure 2. Results of the Structural Model Test

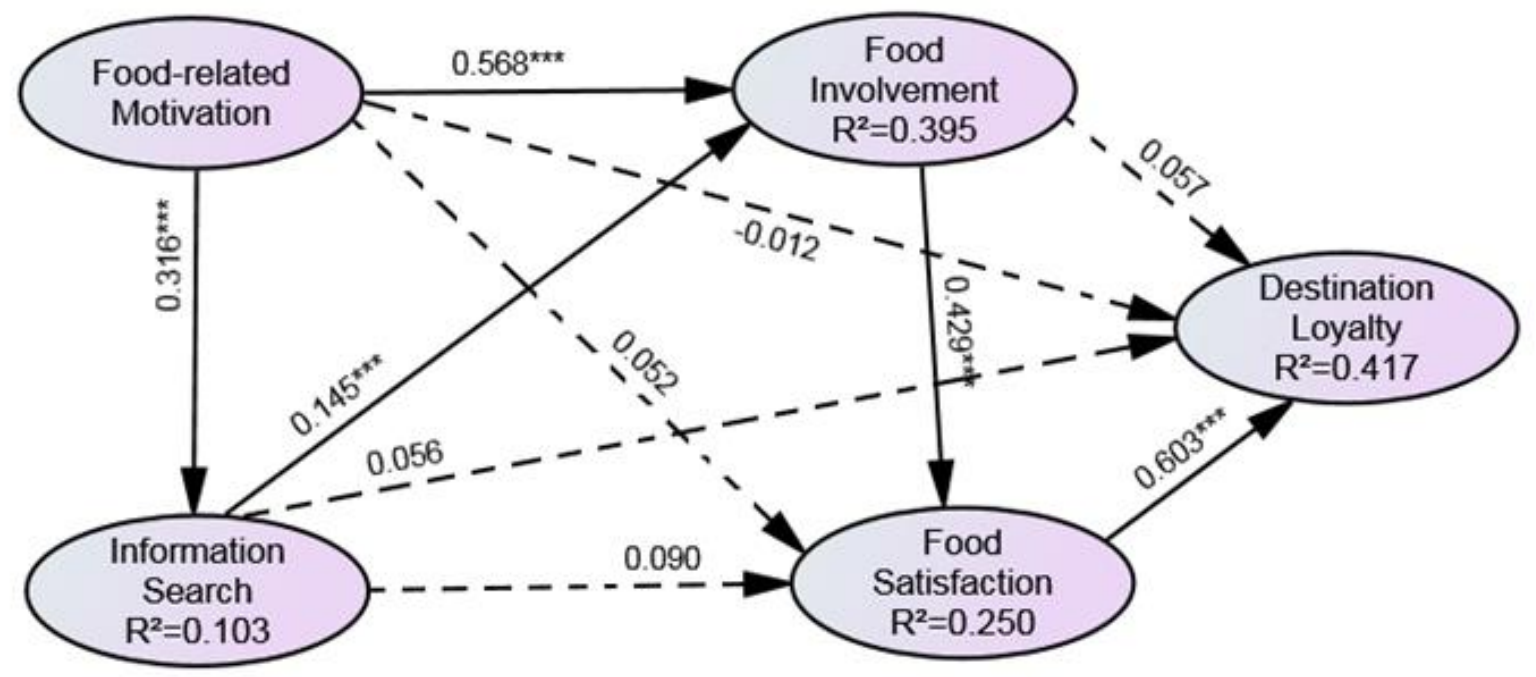

Note: $\longrightarrow \quad$ Indicates singificant path

$--\rightarrow \quad$ Indicates non-significant path

$*$ Significant at $\mathrm{p}<0.10 . \quad * *$ Significant at $\mathrm{p}<0.05 . * * *$ Significant at $\mathrm{p}<0.01$ 